

LINDA J. HARRIS,

Specialist in Cooperative Extension, Microbial Food Safety, Department of Food Science and Technology, University of

California, Davis; KATHERINE E. SOULE, Youth, Families, and

Communities Advisor, University of California Cooperative

Extension, San Luis Obispo and Santa Barbara Counties

\section{Guidelines for Safe Canning of Acid Foods in a Steam Canner}

\section{What Is Steam Canning?}

team canning, or atmospheric steam canning, can be a safe - method for home preservation of most high-acid foods (i.e., foods with $\mathrm{pH}$ of 4.6 or below). The steam canner, also called an atmospheric steam canner, was initially developed in the 1920s as an alternative to the boiling water canner. Steam canning is a more environmentally friendly process than boiling water canning for the following reasons: 1) the steam canner uses much less water than a boiling water canner and 2) the steam canner reaches the required temperature for processing more quickly and thus uses less energy than the boiling water canner.

Several models of steam canners are currently available in the U.S. market. The most common style of steam canner has three elements: a shallow base pan to hold water, a fitted rack that sits on the base, and a high domed cover. The steam canner cover has one or two vent holes near the bottom (figs. 1 and 2). In some steam canner models, the lid handle is also a temperature gauge that indicates when the correct temperature has been reached and timing of the process can



Figure 1. "Back to Basics" steam canner. There are two small vent holes on either side of the bottom of the lid. Photo: Courtesy of National Center for Home Food Preservation.

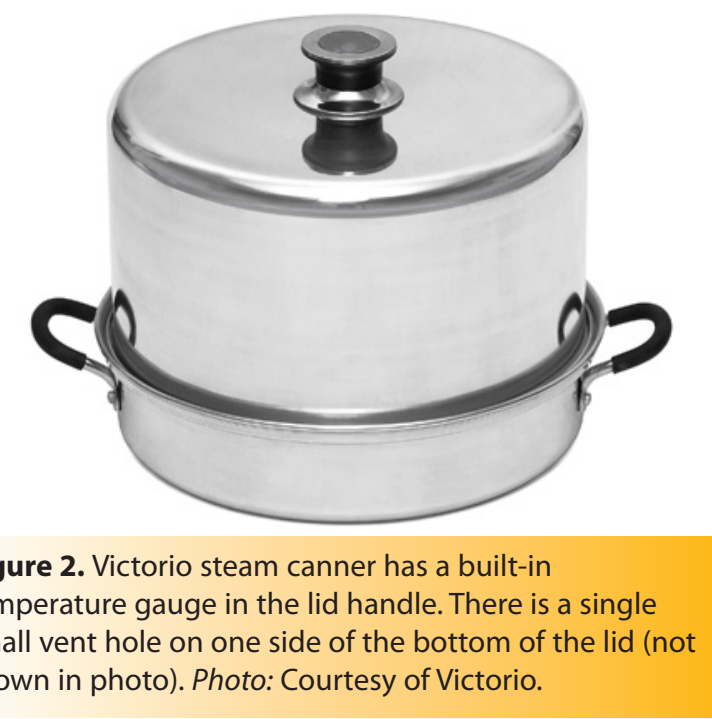


The steam canner is not a pressure canner. The steam inside the steam canner is not under pressure, and temperatures above the boiling point of water

$\left(212^{\circ} \mathrm{F}\right.$, or $100^{\circ} \mathrm{C}$ at sea level) cannot be reached. Steam canning should not be used to can foods that are low in acid (i.e., pH greater than 4.6).

begin (fig. 3). A dual-purpose steam and boiling water canner is also sold (fig. 4). The dual-purpose canner can be filled with water and used as a boiling water canner; and when the canner rack is inverted (to elevate the jars), it may also be used as a steam canner. The lid has vent holes to allow steam to easily escape, ensuring that the heating medium around the jars is pure steam throughout the process.

\section{HOW DOES IT WORK?}

In a steam canner, jars of food are placed above a small amount of water on a rack near the bottom of the canner. As this water boils, it produces steam, which fills the canner. The steam in the canner heats the jars of food. In contrast, in a boiling water canner, jars of food are completely submerged in water and are heated by the boiling water.

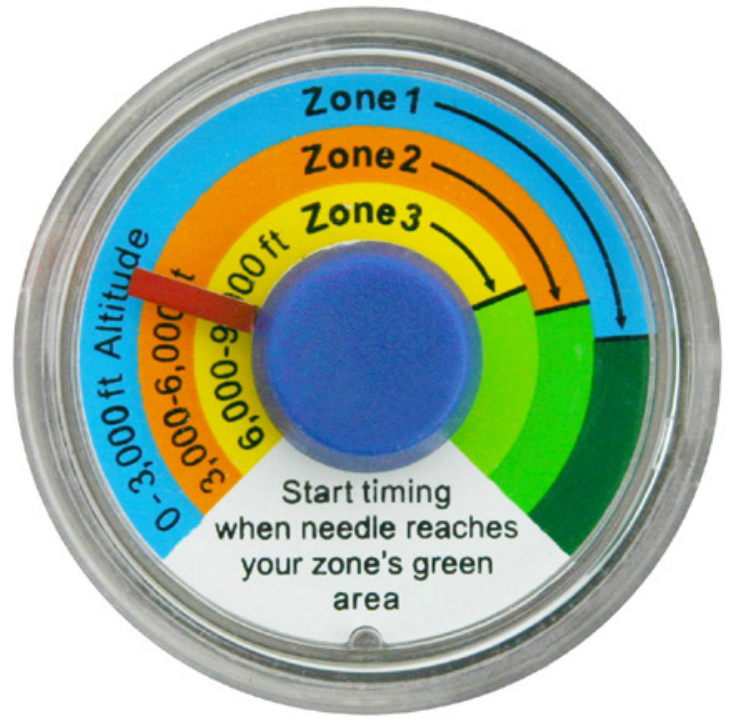

Figure 3. Victorio canner's built-in temperature gauge. Photo: Courtesy of Victorio.

\section{IS IT SAFE?}

In 2015, the University of Wisconsin and the National Center for Home Food Preservation (NCHFP) published new research comparing the safety of a dome-style steam canner with that of a boiling water canner for home processing of high-acid foods (Willmore et al. 2015). Until this time, the U.S. Department of Agriculture (USDA) and the NCHFP did not recommend the use of steam canners for home canning because of the lack of adequate research on safe processing times. The new research showed that most previously validated processing times for use with boiling water canners are also appropriate to use with a steam canner. The guidelines developed by the University of Wisconsin (Ingham 2015) state that a steam canner may be used for home canning of most foods high in acid (i.e., $\mathrm{pH}$ of 4.6 or below) when the specific conditions listed below are met.

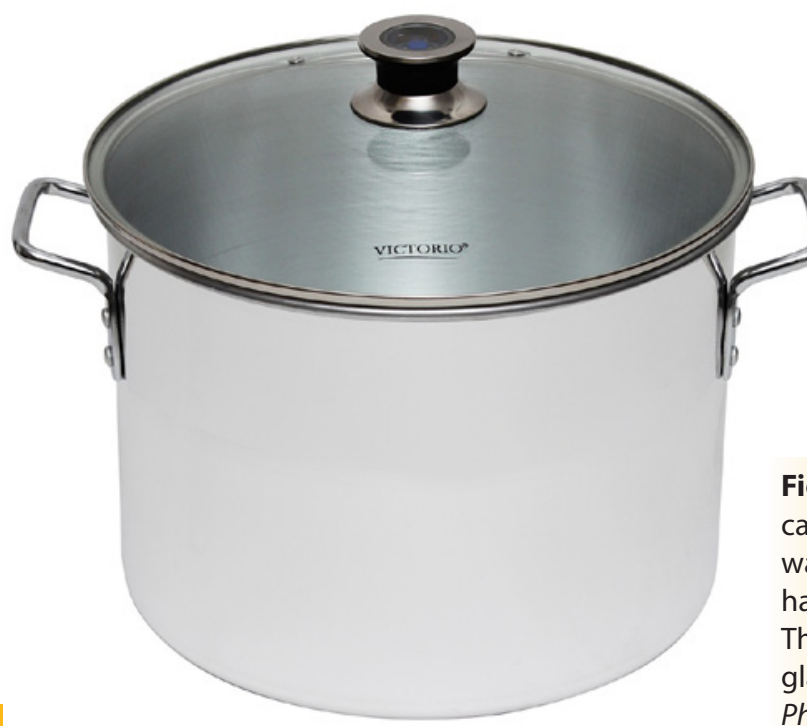

Figure 4. Victorio multi-use canner can be used for either water bath or steam canning. It has a built-in temperature gauge. There are two vent holes in the glass lid (not shown in photo). Photo: courtesy of Victorio. 


\section{Criteria for Safe Use of a Steam Canner}

Most foods that are high in acid can be safely canned in a steam canner, including naturally acidic foods (such as apples, cherries, and peaches) and foods that have been acidified (such as pickles and salsas made from research-tested recipes). However, there are some instances when a steam canner should not be used. See table 1 for a list of foods that can and cannot be safely processed in a steam canner.

Follow these guidelines for home use of steam canners:

1. Always follow a research-tested recipe. Specifically, use research-tested recipes developed for boiling water canners. Recipes must include the quantity of ingredients, the preparation instructions, and processing times for half-pint, pint, or quart jars. For research-tested recipes, visit the National Center of Home Food Preservation website or use the USDA Complete Guide to Home Canning. At this time, recipes in the product manual from the manufacturer of the steam canner are not considered researchtested.

2. Be sure that recipes you use are for foods that are high in acid, with a $\mathrm{pH}$ of 4.6 or below. If you are following a research-tested recipe for a boiling water canner, then the recipe will be for a high-acid food product.

3. Modify processing times for elevations, or altitude, above 1,000 feet, as instructed in research-tested recipes. Elevation for any address can be determined with Google Maps at the DraftLogic website, http://www.daftlogic.com/sandbox-google-maps-findaltitude.htm.

4. Use only recipes that require $\mathbf{4 5}$ minutes or less of processing time, including any additional time for altitude adjustments. Steam canners can run dry if food products are processed longer than 45 minutes, which can damage the canner, food product, and range surface. For recipes that call for processing times greater than 45 minutes (e.g., raw-packed tomatoes), use a boiling water canner. If your steam canner runs dry, your food products must be processed again for the full time indicated in the recipe.

5. Heat jars before filling with food product. Keep the food product as hot as possible by minimizing the time between heating jars and placing them into the steam canner. Also, you can reduce the potential for product cooling by ensuring that water in the canner has reached a boil before preheating and filling jars.

6. Add water to the steam canner as indicated by the manufacturer. The amount of water to add will vary with the manufacturer. Approximately 2 to 3 quarts ( approximately 2 to $3 \mathrm{~L}$ ) of water is typically added to ensure that the water does not run out during the process. The racks allow the jars to sit at or just above the water level and about $1 \frac{1}{4}$ to $13 / 4$ inches ( 3 to $4.5 \mathrm{~cm}$ ) above the base of the pan.

7. Process jars in pure steam $\left(212^{\circ} \mathrm{F}\left(100^{\circ} \mathrm{C}\right)\right.$ at sea level). The processing time should begin only after a full column of steam (approximately 6 to $8 \mathrm{in}$, or 15 to $20 \mathrm{~cm}$ ) appears through the canner vent holes at the bottom of the cover. Some canners come with built-in temperature sensors, which can be used to monitor the temperature. A full column of steam should be present throughout the process time. If there is an interruption in the steam, the product should be reprocessed for the full process time.

8. After processing is finished, turn off the heat source and wait 2 to 3 minutes. Cautiously open the lid away from you and remove the jars.

9. Proper cooling is important for food safety. The research-tested processes include important killing of microorganisms that occurs as the product in the jars cools down. Jars MUST be cooled in still air at room temperature. Jars should be cooled on a rack or towel away from drafts. Do not rush cooling by placing jars in the refrigerator. Do not use a fan or place jars in a drafty area.

Source: Adapted from Ingham 2015 
Table 1. Checklist for some acid or acidified foods that can be safely processed in a steam canner when research-tested recipes are followed

\begin{tabular}{|c|c|c|}
\hline $\begin{array}{l}\text { Processing } \\
\text { safety level }\end{array}$ & Food & Comment (Always follow research-tested recipes) \\
\hline$\checkmark$ & $\begin{array}{l}\text { fruits and fruit products: } \\
\text { apples, apricots, Asian pears (acidified), berries, cherries, crabapples, } \\
\text { cranberries, fruit pureés, peaches, pears, grapes, grapefruit and } \\
\text { orange sections, mangoes, pie fillings, pineapple, plums, rhubarb }\end{array}$ & \\
\hline$\triangle$ & $\begin{array}{l}\text { figs (fresh): } \\
\text { pint jars } \\
\text { quart jars }\end{array}$ & $\begin{array}{l}\text { process time for pint jars exceeds } 45 \text { min at }>1,000 \mathrm{ft}(>300 \mathrm{~m}) \text {; } \\
\text { process time for quart jars at all elevations exceeds } 45 \mathrm{~min}\end{array}$ \\
\hline$\checkmark$ & fruit jams, jellies, conserves, preserves, marmalades & \\
\hline$\checkmark$ & ketchup, barbecue sauce & \\
\hline$\checkmark$ & $\begin{array}{l}\text { pickles } \\
\text { fruit and/or vegetable pickles, relishes, chutneys }\end{array}$ & \\
\hline$\checkmark$ & salsa & \\
\hline$\triangle$ & $\begin{array}{l}\text { tomatillos: } \\
\text { pint jars } \\
\text { quart jars }\end{array}$ & $\begin{array}{l}\text { process time for pint jars exceeds } 45 \mathrm{~min} \text { at }>3,000 \mathrm{ft}(>900 \mathrm{~m}) ; \\
\text { process time for quart jars exceed } 45 \mathrm{~min} \text { at }>1,000 \mathrm{ft}(>300 \mathrm{~m})\end{array}$ \\
\hline$\theta$ & tomatoes, whole or halved, packed in tomato juice & process time for all jar sizes and elevations exceeds $45 \mathrm{~min}$ \\
\hline$\theta$ & tomatoes, whole or halved, packed raw without added liquid & process time for all jar sizes and elevations exceeds $45 \mathrm{~min}$ \\
\hline$\triangle$ & $\begin{array}{l}\text { tomatoes, whole or halved, packed in water: } \\
\text { pint jars } \\
\text { quart jars }\end{array}$ & $\begin{array}{l}\text { process time for pint jars exceeds } 45 \mathrm{~min} \text { at }>3,000 \mathrm{ft}(>900 \mathrm{~m}) \\
\text { process time for quart jars exceeds } 45 \mathrm{~min} \text { at }>1,000 \mathrm{ft}(>300 \mathrm{~m})\end{array}$ \\
\hline$\triangle$ & $\begin{array}{l}\text { tomatoes, crushed (with no added liquid): } \\
\text { pint jars } \\
\text { quart jars }\end{array}$ & $\begin{array}{l}\text { process time for pint jars exceeds } 45 \mathrm{~min} \text { at }>6,000 \mathrm{ft}(>1,800 \mathrm{~m}) \text {; } \\
\text { process time for quart jars exceeds } 45 \mathrm{~min} \text { at }>1,000 \mathrm{ft}(>300 \mathrm{~m})\end{array}$ \\
\hline$\triangle$ & $\begin{array}{l}\text { tomato sauce and tomato juice: } \\
\text { pint jars } \\
\text { quart jars }\end{array}$ & $\begin{array}{l}\text { process time for pint jars exceeds } 45 \mathrm{~min} \text { at }>6,000 \mathrm{ft}(>1,800 \mathrm{~m}) \\
\text { process time for quart jars exceed } 45 \mathrm{~min} \text { at }>3,000 \mathrm{ft}(>900 \mathrm{~m})\end{array}$ \\
\hline
\end{tabular}




\section{References}

Ingham, B. 2015. Safe preserving: Using an atmospheric steam canner. University of Wisconsin Extension website, http://fyi.uwex.edu/safepreserving/2015/06/24/safe-preservingusing-an-atmospheric-steam-canner/.

National Center for Home Food Preservation website, http://nchfp.uga.edu/how/can_home.html.

USDA. 2015. Complete guide to home canning. Rev. National Center for Home Food Preservation (NCGFP) website, https:// nchfp.uga.edu/publications/usda/INTRO_HomeCanrev0715.pdf.

Willmore, P., M. Etzel, E. Andress, and B. Ingham. 2015. Home processing of acid foods in atmospheric steam and boiling water canners. Food Protection Trends 35:150-160.

\section{FOR MORE INFORMATION}

To order or obtain ANR publications and other products, visit the ANR Communication Services online catalog at http://anrcatalog.ucanr.edu/ or phone 1-800-994-8849. You can also place orders by mail or FAX, or request a printed catalog of our products from

University of California

Agriculture and Natural Resources

Communication Services

2801 Second Street

Davis, CA 95618

Telephone 1-800-994-8849

E-mail: anrcatalog@ucanr.edu

(O2017 The Regents of the University of California. This work is licensed under the Creative Commons Attribution-NonCommercial-NoDerivatives 4.0 International License. To view a copy of this license, visit http://creativecommons.org/licenses/by-nc-nd/4.0/ or send a letter to Creative Commons, PO Box 1866, Mountain View, CA 94042, USA.

\section{Publication 8573}

ISBN-13: 978-1-60107-982-4
The University of California, Division of Agriculture and Natural Resources (UC ANR) prohibits discrimination against or harassment of any person in any of its programs or activities on the basis of race, color, national origin, religion, sex, gender, gender expression, gender identity, pregnancy (which includes pregnancy, childbirth, and medical conditions related to pregnancy or childbirth), physical or mental disability, medical condition (cancerrelated or genetic characteristics), genetic information (including family medical history), ancestry, marital status, age, sexual orientation, citizenship, status as a protected veteran or service in the uniformed services (as defined by the Uniformed Services Employment and Reemployment Rights Act of 1994 [USERRA]), as well as state military and naval service.

UC ANR policy prohibits retaliation against any employee or person in any of its programs or activities for bringing a complaint of discrimination or harassment. UC ANR policy also prohibits retaliation against a person who assists someone with a complaint of discrimination or harassment, or participates in any manner in an investigation or resolution of a complaint of discrimination or harassment. Retaliation includes threats, intimidation, reprisals, and/or adverse actions related to any of its programs or activities.

UC ANR is an Equal Opportunity/Affirmative Action Employer. All qualified applicants will receive consideration for employment and/or participation in any of its programs or activities without regard to race, color, religion, sex, national origin, disability, age or protected veteran status.

University policy is intended to be consistent with the provisions of applicable State and Federal laws.

Inquiries regarding the University's equal employment opportunity policies may be directed to: John Sims, Affirmative Action Contact and Title IX Officer, University of California, Agriculture and Natural Resources, 2801 Second Street, Davis, CA 95618, (530) 750-1397. Email: jsims@ucanr.edu. Website: http://ucanr.edu/sites/anrstaff/Diversity/Affirmative_Action/.

To simplify information, trade names of products have been used. No endorsement of named or illustrated products is intended, nor is criticism implied of similar products that are not mentioned or illustrated.

An electronic copy of this publication can be found at the ANR Communication Services catalog website, http://anrcatalog.ucanr.edu/.

UC This publication has been anonymously peer reviewed for technical accuracy PEER by University of California scientists and other qualified professionals. Nutrition Karina Diaz Rios.

This review process was managed by ANR Associate Editor for Food and

web-09/17-LR/CR 